https://doi.org/10.48009/2_iis_2008_361-368

\title{
E-SOCIAL BEHAVIOR: ARE ACADEMIC CLASS AND IDENTITY THEFT FACTORS?
}

\author{
Carl J. Case, St. Bonaventure University, ccase@sbu.edu \\ Darwin L. King, St. Bonaventure University, dking@sbu.edu \\ Michael D. Kasperski, St. Bonaventure University, mkaspers@sbu.edu \\ Ann H. Lehman, St. Bonaventure University, alehman@sbu.edu
}

\begin{abstract}
E-socializing is growing in popularity in the business world. Little research, however, has been conducted to examine the e-social group behavior of the soon to be business professionals, the undergraduates. This study, therefore, was conducted to empirically investigate student behavior and perceptions. Results suggest that $e$-socializing is common among students and varies by academic class. Moreover, there is a disparity between student indication of importance and level of activity. Finally, student worry about identity theft varies by academic class and e-social activity.
\end{abstract}

Keywords: Social groups, myspace, facebook, undergraduates, empirical survey, e-social behavior

\section{INTRODUCTION}

Online social networking, or e-socializing, has seen dramatic growth in participation. The number of unique visitors to Facebook, for example, increased 270\% from 14 million to 52 million from June 2006 to June 2007 [7]. During the same time frame, MySpace increased by $72 \%$ from 66 million to 114 million unique visitors. In terms of time, in January 2008, users spent an average of 204 minutes per visit on MySpace, 30 minutes more time on average than Facebook [10].

A survey of US college students found Facebook was the second most popular pastime (along with sex) after listening to the iPod [12]. The Chinese Government once even tried unsuccessfully to ban it and other interactive networks. But now there are more than 100,000 Chinese members in China's English-language Facebook.

Uses of online networking vary. A study of UK users found that $75 \%$ of respondents use online sites to keep in touch with family and friends, $62 \%$ to be "nosey," $55 \%$ to express opinions and views, and $49 \%$ to meet people with similar interests [6]. The majority, $70 \%$, of social networking activity occurred during the evening. An April 2007 study commissioned by Fox Interactive Media, Inc. surveyed over 3,000 US individuals had similar findings [9]. Researchers found that $68 \%$ of respondents visit social networking sites in the evening, $58 \%$ use social sites to communicate/stay in touch, $44 \%$ to re-establish old contacts, $38 \%$ for entertainment, and $30 \%$ for finding people with the same interest.

Social networking is even melding with online video gaming. KartRider and Kaneva are games that allow friends and strangers to chat, compare fashions, dance, purchase virtual clothing, and slay monsters in a virtual environment [14]. Facebook and MySpace are also involved in developing games. PicksPal, for example, is a company that permits Facebook users to predict the winners in sporting events and awards them points for being correct [15]. The points can then be cashed in for prizes.

One of the newest forms of social networking is the electronic business network. IBM has used social networking technologies internally since 2003 and now markets Lotus Connections software to its corporate customers to help transfer internal and external communications into a social computing format. [17] Linkedln, a fast growing social network, has 13,000 recruiter and 9 million professional members of which 1.2 million members are senior executives. Corporate subscribers include Microsoft, FedEx, Deloitte \& Touche, Sony, and eBay. In mid 2007, Facebook also began offering the opportunity for any company, Internet service, software maker, or anyone to build services for its members. The major business networks on Facebook include Microsoft, Ernst \& Young, Deloitte \& Touche, Accenture, and Hewlett-Packard. The largest government work networks include the U.S. military branches, the U.K. National Health Service, the U.K. Civil Service, and the Canadian Forces.

Businesses are also using social networks to assist in hiring. According to a Ponemon Institute survey, 23\% of hiring managers use social networking sites to do online background checks and 35\% use Google to look up information about individuals [1]. Approximately $33 \%$ of those searches led to rejection of the applicant. Interesting, Adecco, a workforce consulting firm, found that $66 \%$ of those in their late teens or twenties were 
unaware that information they place online is factored into hiring decisions [13]. One infamous result occurred at Millersville University of Pennsylvania. Stacy Snyder, a student, was not awarded her degree in Education when university administrators discovered a photo of her on her MySpace page labeled "drunken pirate”.

A survey at the University of Dayton, Ohio, further points to the disconnect that exists between students and the adults who make decisions about them [8]. The researchers polled 2,000 students at colleges in the Dayton area and more than 300 employers. Results indicated that while $40 \%$ of employers believe that is OK to use Facebook when making a hiring decision, only $19 \%$ of students agreed. Sixty percent of students stated that employers should not consider a Facebook entry. In addition, 32\% of students believed that employers' use of Facebook is illegal and $42 \%$ considered this to be a violation of privacy. Only onequarter of employers considered it unethical and 21\% indicated that it is a violation of privacy.

Another aspect of social networking relates to identity theft. Sophos conduced an ID probe to examine the risks of information theft [18]. In the study, Sophos fabricated a Facebook profile, Freddi Staur (an anagram for "ID fraudster") and sent out 200 friend requests. Forty-one percent of respondents agreed to be friends and reveal access to personal data. The probe found that $84 \%$ listed their full date of birth, $78 \%$ listed their current address or location, 26\% provided their instant messaging screen name, and 23\% listed their current phone number.

As e-socializing is becoming more mainstream and growing in importance in business, it is important, therefore, to have a better understanding of undergraduate e-social behavior. There are several resultant research questions. Is student e-socializing prevalent? Does academic class play a role? Is there a relationship between e-socializing and negative outcomes such as identity theft? As a result, this study was undertaken to gain insight into student behavior and perceptions.

\section{PREVIOUS RESEARCH}

Prior research has examined various factors such as geographic distribution, socialization, civic involvement, social searching and development of social capital through social networking. These studies examine the appeal of social networking sites by individuals in general and students in particular.
Fusilier et al, for example, examined college students' frequency and extent of Internet use as well as selfreports of factors facilitating usage [3]. The study sample was drawn from four countries that varied in level of economic development. Findings indicate that Internet access was a major factor contributing to greater usage by western students than by their counterparts in non-western countries. The study concludes that non-western students had less training and access to the Internet. This suggests that the training and access that western universities provide through infrastructure and university support facilitate social Internet use.

Jones also examined online activities. In 2002, Jones found that $86 \%$ of college students were online [5]. College students frequently checked email with $72 \%$ checking email at least once a day. Moreover, $42 \%$ of students indicated that they used the Internet primarily to communicate socially. Seventy-two percent of their online communications was with friends, $10 \%$ with family, seven percent with professors, six percent with romantic partners, and five percent with work colleagues. According to $62 \%$ of the respondents, the most popular form of communication was email. Overall, 85\% of college students considered the Internet to be an easy and convenient choice for communicating with these groups. Moreover, results suggest that students view the Internet as a valuable tool in their education. The majority of respondents, $79 \%$, indicated the Internet had a positive impact on their college academic experience and $73 \%$ of the students used the Internet more than the University’s library. In addition, results indicate that communication with professors and fellow students was greatly enhanced by the Internet and email.

The extensive use of the Internet for social use is supported further by research by Parks and Floyd [11]. Results found that just over $60 \%$ of a random sample of individuals in an Internet newsgroup reported forming a personal relationship with someone they had first contacted through a newsgroup. In addition, nearly two-thirds of those whose personal relationship began online chose to have other forms of contact as well.

Horrigan found the Internet may be drawing a segment of the young population to become engaged in civic activities [4]. The survey of 1,697 Internet users found that $84 \%$ of the users contacted an online group. Moreover, the study found that younger people reluctant to participate in community groups are finding an outlet through the Internet. Younger people tend to be drawn to the Internet by social cites and gravitate to other online communities that foster civic engagements. 
Examples include the student formation of a Facebook group that was used to aid in the search for a new president at the University of Iowa and the usage of Facebook by professional politicians campaigning for office [8]. Mercyhurst College in Erie, Pennsylvania has even requested that faculty and staff join Facebook in order to have a "norming influence" on what is placed on student Facebook profiles and pictures.

Results from a 2007survey of undergraduate students suggest a strong association between use of Facebook and social capital, with the strongest relationship being to bridging social capital [2]. Social capital can be defined as the sum of the resources, actual or virtual, that accrue to an individual or a group by virtue of possessing a durable network of more or less institutionalized relationships of mutual acquaintance and recognition. For individuals, social capital allows a person to draw on resources from other members of the networks to which he or she belongs. These resources can take the form of useful information, personal relationships, or the capacity to organize groups. Bridging social capital is linked to what network researchers refer to as "weak ties," which are loose connections between individuals who may provide useful information or new perspectives for one another but typically not emotional support. Results also indicate that Facebook usage was found to interact with measures of psychological well-being, suggesting that it might provide greater benefits for users experiencing low self-esteem and low life satisfaction.

And, recognizing the importance of online social networks and their influence on the adoption and use of products and services, Subramani and Rajagopalan introduced a theoretical framework for study [16]. They examined viral marketing, the tactic of creating a process where interested individuals can market to each other. The framework utilizes the constructs of the role of the influencer (active or passive) and the level of network externalities (the additional benefits accruing from broader usage of the product or service).

\section{RESEARCH DESIGN}

This study employs a survey research design. The research was conducted at a private northeastern U.S. university. A Student E-Social Behavior survey instrument was developed and administered during a three-consecutive semester period (Fall 2006, Spring 2007, and Fall 2007) to undergraduate students enrolled in a School of Business course. The sample had a 100\% response rate and included a variety of courses such as BIS-310 "Business Information Systems", BIS-310 "Business Telecommunications”, BIS-335 "System
Analysis and Design”, ACCT-201 "Introduction to Financial Accounting", ACCT-202 "Introduction to Managerial Accounting", and MSC-413 "Business Policy.” A convenience sample of class sections was selected in order to maximize student participation. The class sections were conducted by a variety of faculty.

The survey instrument was utilized to collect student demographic data and examine student behavior with regard to electronic social groups. The survey requested that each student estimate the number of hours per week that he/she visited social sites and the locations where each student posted his/her personal information. In addition, students were prompted to identify the degree of importance that social sites are to him/her and to indicate his/her level of worry with regard to identity theft. The survey was administered during the final week of each of the 15-week semesters and all surveys were anonymous. Moreover, students were informed that results would have no effect on their semester grade.

\section{RESULTS}

A sample of 643 usable surveys was obtained. Sixtyfour percent of the respondents were male and 36\% were female (Table1). The response rate by academic class is distributed among Freshmen, Sophomore, Junior, and Senior classes. Nineteen percent of respondents were freshmen, 19\% were sophomores, $31 \%$ were juniors, and 31\% were seniors (Table 2).

\section{<Insert Table 1 here $>$}

\section{$<$ Insert Table 2 here $>$}

To examine behavior, each student was requested to estimate the number of hours per week that he/she visited various social sites. Table 3 details the activity, percentage of students who indicated that activity, and number of hours. Results show that $81 \%$ of students visit Facebook each week. In addition, 28\% visit MySpace and $8 \%$ visit social groups such as phishbook.com, sconex.com, livejournal, and sports interest groups. In terms of time, 8.5 hours per week was spent visiting Facebook, 4.0 hours visiting MySpace, and 3.8 hours visiting other social sites. Moreover, $77 \%$ of respondents indicated posting information about themselves on Facebook. Twentysix percent post information on MySpace and 3\% post on other sites. Overall, $84 \%$ of undergraduates indicated using at least one social site. In addition, 9.9 hours were expended each week visiting social sites. In terms of site posting, significant differences at the .001 
level in academic class occurred with regard to Facebook. There was no academic class difference with regard to MySpace or any other social site. When examining respondent perception of social site importance with the various behaviors, there were correlations significant at the .001 level with all visiting and posting behaviors except posting on "another social site.” When examining respondent perception of worry about identity theft with the various behaviors, there were correlations significant at the .001 level with regard to visiting Facebook and posting information on Facebook. The only other correlation, significant at the .01 level, was with regard to posting information on MySpace.

\section{<Insert Table 3 here>}

The study next examined behavior by academic class (Table 4). Results indicate that $90 \%$ of freshmen, $90 \%$ of sophomores, $83 \%$ of juniors, and $75 \%$ of seniors visit social sites. Moreover, $84 \%$ of freshmen, $90 \%$ of sophomores, $80 \%$ of juniors, and $69 \%$ of seniors post personal information on social sites. Overall, 91\% of freshmen, $92 \%$ of sophomores, $87 \%$ of juniors, and $77 \%$ of seniors exhibit either behavior. In terms of social site visit time, freshmen spent 15.4 hours per week, sophomores spent 6.5 hours per week, juniors spent 5.8 hours per week, and seniors spent 7.2 hours per week.

\section{$<$ Insert Table 4 here $>$}

Students were also prompted to indicate the level of importance that social sites are to them (Table 5). With regard to freshmen, $30 \%$ feel that social sites are not important and 52\% feel that social sites are somewhat important. With regard to sophomores, 39\% feel that social sites are not important and 48\% feel that social sites are somewhat important. With regard to juniors, $41 \%$ feel that social sites are not important and $47 \%$ feel that social sites are somewhat important. With regard to seniors, $49 \%$ feel that social sites are not important and 33\% feel that social sites are somewhat important. A Pearson Chi-Square test indicates a .001 significance difference among academic class with regard to the importance response.

\section{$<$ Insert Table 5 here $>$}

Finally, students were asked to indicate the level of worry about identity theft (Table 6). With regard to freshmen, 37\% never or rarely worry about identity theft and $43 \%$ sometimes worry. With regard to sophomores, $40 \%$ never or rarely worry about identity theft and $48 \%$ sometimes worry. With regard to juniors, $48 \%$ never or rarely worry about identity theft and $39 \%$ sometimes worry. With regard to seniors, $47 \%$ never or rarely worry about identity theft and 38\% sometimes worry. A Pearson Chi-Square test indicates a .001 significance difference among academic class with regard to worry response.

\section{$<$ Insert Table 6 here $>$}

\section{CONCLUSIONS AND FUTURE RESEARCH}

Overall, this study is useful in providing a better understanding of student e-socializing. Results show that $84 \%$ of students admit to using electronic social sites. Eighty-one percent visit Facebook, 28\% visit MySpace, and 8\% visit other sites such as phishbook.com, sconex.com, and livejournal. On average, 9.9 hours per week is expended visiting these sites. Respondents indicated spending 8.5 hours visiting Facebook, 4.0 hours visiting MySpace, and 3.8 hours visiting other sites per week.

This study also found that $77 \%$ of students have personal information posted on Facebook, 26\% on MySpace, and $3 \%$ on another social group site. Overall, $84 \%$ of freshmen, $90 \%$ of sophomores, $80 \%$ of juniors, and $69 \%$ of seniors post personal information on social sites. Moreover, freshmen spent 15.4 hours per week, sophomores spent 6.5 hours per week, juniors spent 5.8 hours per week, and seniors spent 7.2 hours per week visiting social sites.

Furthermore, results indicate that 30\% of freshmen feel that social sites are not important to them and that $9 \%$ feel that social networking is very important. In terms of sophomores, $39 \%$ indicate that social networking is not important while 4\% indicate that social networking is very important. In terms of juniors, $41 \%$ indicate that social networking is not important while $4 \%$ indicate that social networking is very important. In terms of seniors, $49 \%$ indicate that social networking is not important while $6 \%$ indicate that social networking is very important.

Finally, student worry about identity theft varies by academic class, at the .001 Chi-Square level of significance. Forty-nine percent of freshmen, 55\% of sophomores, $43 \%$ of juniors, and $47 \%$ of seniors either worry sometimes or a lot about identity theft.

There are four important implications as a result of these findings. It appears that electronic social networking is common. The preference and use of electronic social networking sites implies that students are comfortable with and value electronic relationships. 
This questions whether face-to-face communication skills will suffer and not be appropriately developed while in college. It is also not known if students are practicing responsible behavior in their social networking with friends and strangers. Future research is needed to explore if students are presenting an electronic persona that increases the likelihood of identity theft, cyber-stalking, or profiling. In addition, there is also the question of whether undergraduates portray themselves in a degrading manner that could be detrimental if a potential employer, insurer, or other party viewed it.

A second implication is that academic class is a factor with regard to social networking. While $90 \%$ of freshmen visit social sites, only $75 \%$ of seniors visit social sites. In addition, $84 \%$ of freshmen post data but only $69 \%$ of seniors exhibit the same behavior. Moreover, visit time for freshmen is 15.4 hours per week but visit time for seniors is 7.2 hours, a 53\% decrease. Response by class was significantly different with regard to posting, indications of importance, and worry about identity theft. It is likely that e-socializing is important to freshmen as they seek to continue relationships established in high school. The time and participation may decrease as new social groups are established while in college and substitution activities such as clubs increase throughout the collegiate years. During the senior year, fewer students either visit or post to social sites but expended time does increase from the junior year. This increase may be a result of seniors seeking to establish connections in hopes of obtaining jobs upon graduation. Senior accounting majors at the study organization, for example, are encouraged to develop e-social relationships for this reason.

A third implication is that there is a disparity between student indication of importance and level of activity. There were correlations significant at the .001 level between importance and all behaviors except posting on "another social site." However, while 30\% of freshmen indicate that social sites are not important, $90 \%$ visit social sites and $84 \%$ have posted their personal information. While $39 \%$ of sophomores indicate that social sites are not important, $90 \%$ visit social sites and $90 \%$ have posted their personal information. While $41 \%$ of juniors indicate that social sites are not important, $83 \%$ visit social sites and $80 \%$ have posted their personal information. And, while $49 \%$ of seniors indicate that social sites are not important, $75 \%$ visit social sites and $69 \%$ have posted their personal information. Future research is needed to understand the motivators driving students to e-social sites and what types of fulfillment are derived from this activity.
A forth implication is that student worry about identity theft does vary by academic class and by activity. While $11 \%$ of freshmen never worry about identity theft, only $2 \%$ of sophomores never worry. Moreover, while $4 \%$ of juniors worry a lot, $9 \%$ of seniors worry a lot. Overall, a Pearson Chi-Square test indicates a .001 significance difference among academic class with regard to worry response. When examining worry about identity theft and behavior, there was a highly significant correlation with regard to visiting Facebook and with regard to posting on Facebook. It is uncertain, however, why Facebook is more worrisome than MySpace and other social sites. Further research is needed to determine whether students post personal information that can be utilized for identity theft and/or realize that such information can be stolen. Results from the Sophos study suggest that students are naïve about identity theft with regard to the content of their esocial postings.

The limitations of this study are primarily a function of sample size, sample distribution, and type of research. A larger sample size, more equal distribution among academic class and gender, and use of additional universities would increase the robustness of results. Another limitation relates to the self-reported nature of the survey. Future research is also needed to explore if these social relationships improve the success of graduates.

\section{REFERENCES}

1. Du, W. (2007). Job Candidates Getting Tripped Up by Facebook. Msnbc.com, August 14 Available: http://www.msnbc.msn.com/id/20202935/

2. Ellison, N. B., Steinfield, C., \& Lampe, C. (2007). The benefits of Facebook "friends:" Social capital and college students' use of online social network sites. Journal of Computer-Mediated Communication, 12(4), article 1. Available: http://jcmc.indiana.edu/vol12/issue4/ellison.html

3. Fusiler, M., Durlabhji, S, Cucchi, A., \& Collins, M. (2005). A Four-Country Investigation of Factors Facilitating Student Internet Use. CyberPsychology \&Behavior, 8(5), 454-463.

4. Horrigan, J. B. (2001). Online Communities: Networks That Nuture Long-distance Relationships and Local Ties. Pew Internet \& America Life Project, October 31. Available: http://www.pewinternet.org

5. Jones, S. (2002). The Internet Goes to College. Pew Internet \& American Life Project, September 15. Available: http://www.pewinternet.org 
6. Koterwas, T. (2007). Social Networking Statistics. Wdil.org, June 9. Available: http://www.wdil.org/resources/social-networkingstatistics

7. Lipsman, A. (2007). Social Networking Goes Global. comScore, July 31. Available: http://www.comscore.com/press/release.asp?press $=1555$

8. Lupsa, C. (2006). Facebook: A Campus Fad Becomes A Campus Fact. The Christian Science Monitor, December 13, 13.

9. Nagy, J. \& Wachs, J. (2007). Never Ending Friending. Fox Interactive Media, Inc., April. Available: http://www.tnsus.com/knowledge/docs/40161_Online_Book.pdf

10. Netherby, J. (2008). Socially Awkward? Still Incredibly Trafficked, MySpace and Facebook Level Off. Billboard, 120(8), 12.

11. Parks, M. \& Floyd, K. (1996). Making Friends in Cyberspace. Journal of Communication, 46(1), 80-97.

12. Patterson, B. (2008). Facing up to the Future: How Cyber Social Networking Site FaceBook Has Taken the World By Storm. Sunday Herald Sun
(Australia), February 17, 88.

13. Reed, B. (2007). A MySpace Photo Costs A Student A Teaching Certificate. The Chronicle of Higher Education, April 27. Available: http://chronicle.com/wiredcampus/index.php?id=2 029

14. Slagle, M. (2007). Online Video Games Meet Social Networking Tools. The Times Herald, November 25, B-1.

15. Stone, B. (2007). Facebook Goes Off the Campus. The New York Times, May 25, C2.

16. Subramani, M. R. \& Rajagopalan, B. (2003). Knowledge-Sharing and Influence in Online Social Networks via Viral Marketing. Communications of the ACM, 46(12), 300-307.

17. Wildstrom, S. H. (2007). Harnessing Social Networks. BusinessWeek, 4031, April 23, 20.

18. ---- (2007). Sophos Facebook ID Probe Finds Users Reveal Too Much. August 14. Available: http://www.marketingcharts.com/interactive/sopho s-facebook-id-probe-finds-users-reveal-too-much1279/

\section{TABLES AND FIGURES}

Table 1. Response Rate By Gender

\begin{tabular}{||l|c|r||}
\hline \multicolumn{1}{|c|}{ Class } & Count & Percentage \\
\hline \hline Male & 409 & $64 \%$ \\
\hline Female & 234 & $36 \%$ \\
\hline \hline Female & 643 & $100 \%$ \\
\hline
\end{tabular}

Table 2. Response Rate By Academic Class

\begin{tabular}{||l|r||}
\hline \multicolumn{1}{|c|}{ Class } & Percentage \\
\hline \hline Freshmen & $19 \%$ \\
\hline Sophomore & $19 \%$ \\
\hline Junior & $31 \%$ \\
\hline Senior & $31 \%$ \\
\hline
\end{tabular}

Table 3. E-Socializing by Type

\begin{tabular}{||l|c|c|c|c|c||}
\hline Activity & $\begin{array}{c}\text { \% of } \\
\text { Students }\end{array}$ & $\begin{array}{c}\text { Hours } \\
\text { Per } \\
\text { Week }\end{array}$ & $\begin{array}{c}\text { Chi-Square } \\
\text { Class } \\
\text { Differences }\end{array}$ & $\begin{array}{c}\text { Pearson } \\
\text { Chi-Square } \\
\text { with } \\
\text { Importance }\end{array}$ & $\begin{array}{c}\text { Pearson } \\
\text { Chi-Square } \\
\text { with Worry }\end{array}$ \\
\hline \hline
\end{tabular}




\begin{tabular}{||l|r|r|r|r|r||}
\hline \multicolumn{1}{|c|}{ Activity } & $\begin{array}{c}\text { \% of } \\
\text { Students }\end{array}$ & $\begin{array}{c}\text { Hours } \\
\text { Per } \\
\text { Week }\end{array}$ & $\begin{array}{c}\text { Chi-Square } \\
\text { Class } \\
\text { Differences }\end{array}$ & $\begin{array}{c}\text { Pearson } \\
\text { Chi-Square } \\
\text { with } \\
\text { Importance }\end{array}$ & $\begin{array}{c}\text { Pearson } \\
\text { Chi-Square } \\
\text { with Worry }\end{array}$ \\
\hline \hline Visit Facebook & $81 \%$ & 8.5 & & $211.623^{* * *}$ & $150.635^{* *}$ \\
\hline Visit MySpace & $28 \%$ & 4.0 & & $107.782^{* * *}$ & 40.263 \\
\hline Visit another social site & $8 \%$ & 3.8 & & $60.419^{* * *}$ & 24.429 \\
\hline $\begin{array}{l}\text { I have my information posted on } \\
\text { Facebook }\end{array}$ & $77 \%$ & & $70.367^{* * *}$ & $33.011^{* * *}$ & $37.121^{* * *}$ \\
\hline $\begin{array}{l}\text { I have my information posted on } \\
\text { MySpace }\end{array}$ & $26 \%$ & & 9.775 & $33.513^{* * *}$ & $9.081^{*}$ \\
\hline $\begin{array}{l}\text { I have my information posted on } \\
\text { another social site }\end{array}$ & $3 \%$ & & 5.2000 & 5.827 & 6.636 \\
\hline \hline \multicolumn{1}{|l|}{ Overall visiting average } & $84 \%$ & 9.9 & & & \\
\hline
\end{tabular}

* Significant at the .01 level

** Significance at .005 level

*** Significance at .001 level

Table 4. E-Socializing by Academic Class

\begin{tabular}{||c|r|r|r|r||}
\hline \multicolumn{1}{|c|}{ Activity } & \multicolumn{1}{c|}{$\begin{array}{c}\text { \% of } \\
\text { Freshmen }\end{array}$} & $\begin{array}{c}\text { \% of } \\
\text { Sophomores }\end{array}$ & $\begin{array}{c}\text { \% of } \\
\text { Juniors }\end{array}$ & $\begin{array}{c}\text { \% of } \\
\text { Seniors }\end{array}$ \\
\hline \hline Visit social sites & $90 \%$ & $90 \%$ & $83 \%$ & $75 \%$ \\
\hline Post personal information on a social site & $84 \%$ & $90 \%$ & $80 \%$ & $69 \%$ \\
\hline Either Visit or Post & $91 \%$ & $92 \%$ & $87 \%$ & $77 \%$ \\
\hline \hline Hours visiting social sites & 15.4 & 6.5 & 5.8 & 7.2 \\
\hline
\end{tabular}

Table 5. Importance of Social Sites by Academic Class

\begin{tabular}{||l|r|r|r|r|r||}
\hline Academic Class & \multicolumn{1}{|c|}{ Not } & Somewhat & \multicolumn{1}{c|}{ Very } & \multicolumn{1}{c|}{$\begin{array}{c}\text { No } \\
\text { Response }\end{array}$} & $\begin{array}{c}\text { Chi-Squared } \\
\text { Class } \\
\text { Differences }\end{array}$ \\
\hline \hline Freshman & $30 \%$ & $52 \%$ & $9 \%$ & $10 \%$ & \\
\hline Sophomore & $39 \%$ & $48 \%$ & $4 \%$ & $9 \%$ & \\
\hline Junior & $41 \%$ & $47 \%$ & $4 \%$ & $8 \%$ & \\
\hline Senior & $49 \%$ & $33 \%$ & $6 \%$ & $12 \%$ & \\
\hline \hline Overall & $41 \%$ & $44 \%$ & $6 \%$ & $9 \%$ & $40.086^{* * *}$ \\
\hline
\end{tabular}

* Significant at the .01 level

** Significance at .005 level

$* * *$ Significance at .001 level

Table 6. Worry About Identity Theft 


\begin{tabular}{||c|r|r|r|r|r|r||}
\hline $\begin{array}{c}\text { Academic } \\
\text { Class }\end{array}$ & Never & Rarely & Sometimes & \multicolumn{1}{c|}{ A lot } & \multicolumn{1}{c|}{$\begin{array}{c}\text { No } \\
\text { Response }\end{array}$} & $\begin{array}{c}\text { Chi-Squared } \\
\text { Class } \\
\text { Differences }\end{array}$ \\
\hline \hline Freshman & $11 \%$ & $26 \%$ & $43 \%$ & $6 \%$ & $14 \%$ & \\
\hline Sophomore & $2 \%$ & $38 \%$ & $48 \%$ & $7 \%$ & $5 \%$ & \\
\hline Junior & $11 \%$ & $37 \%$ & $39 \%$ & $4 \%$ & $9 \%$ & \\
\hline Senior & $10 \%$ & $37 \%$ & $38 \%$ & $9 \%$ & $6 \%$ & \\
\hline \hline Overall & $9 \%$ & $34 \%$ & $41 \%$ & $6 \%$ & $9 \%$ & $81.459^{* * *}$ \\
\hline
\end{tabular}

* Significant at the .01 level

** Significance at .005 level

*** Significance at .001 level 